Gut, 1975, 16, 105-108

\title{
Influence of dehydrocholate and taurocholate on bromsulphthalein uptake, storage, and excretion in the dog
}

\author{
Y. DELAGE, S. ERLINGER ${ }^{1}$, M. DUVAL, AND J.-P. BENHAMOU \\ From the Unité de Recherches de Physiopathologie Hépatique (INSERM), Hôpital Beaujon, Clichy, France
}

SUMMARY The influence of dehydrocholate on bromsulphthalein relative-storage capacity, biliary transport maximum ( $\mathrm{Tm}$ ), and fractional transfer rates between plasma, liver, and bile have been studied in unanaesthetized dogs. In six dogs, storage capacity, Tm, and fractional transfer rates from plasma to liver, liver to bile, and liver to plasma were measured during $0.15 \mathrm{M} \mathrm{NaCl}$ infusion and the measurements were repeated under a dehydrocholate infusion of $95 \mu \mathrm{mol}_{\text {.min }}^{-1}$, ie, an infusion rate approaching the known biliary $\mathrm{Tm}$ of bile salts. It was found that: (a) storage capacity and fractional transfer rates from plasma to liver were significantly lower during dehydro-

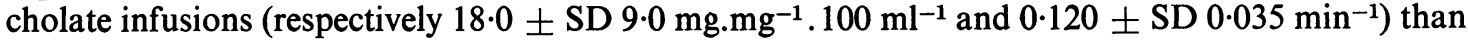
during $\mathrm{NaCl}$ infusions (respectively $47.0 \pm 21.0 \mathrm{mg} \cdot \mathrm{mg}^{-1} .100 \mathrm{ml}^{-1}$ and $0.280 \pm \mathrm{SD} 0.055 \mathrm{~min}^{-1}$; $\mathbf{P}<0.001) ;(b) \mathrm{Tm}$ and fractional transfer rates from liver to bile were also significantly lower during dehydrocholate infusions (respectively $3.2 \pm$ SD $1.1 \mathrm{mg} \cdot \mathrm{min}^{-1}$ and $0.013 \pm$ SD $0.004 \mathrm{~min}^{-1}$ )

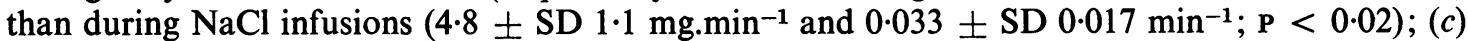
in three additional experiments, taurocholate had similar effects on storage capacity and $\mathrm{Tm}$. These findings suggest that competition occurred between bile salts and bromsulphthalein for hepaticuptake and storage. They support the hypothesis that the decreased disappearance rate and relative storage capacity of bromsulphthalein observed during biliary obstruction may be due to competition between bile salts and bromsulphthalein for hepatic uptake and storage.

Hepatobiliary elimination of bromsulphthalein (BSP) involves three major stages; hepatocellular uptake, intracellular transport (including conjugation and storage), and excretion into bile canaliculi (Leevy, 1961; Javitt, 1970). Measurement of relative storage capacity and maximal biliary excretion (transport maximum or $\mathrm{Tm}$ ) provides a means of assessing quantitatively the storage function of the hepatocytes and their capacity for biliary excretion (Wheeler, Epstein, Robinson, and Snell, 1960a; Wheeler, Meltzer, and Bradley, 1960c). It had been anticipated that the relative storage capacity would be predominantly decreased in hepatocellular disease, whereas Tm would be more specifically altered in disorders of biliary function (Wheeler $e t$ al, 1960c); thus simultaneous measurement of storage capacity and $\mathrm{Tm}$ would have provided a

\footnotetext{
${ }^{1}$ Requests for reprints to S.E., Unité de Recherches de Physiopathologie Hépatique, Hôpital Beaujon, 92110 Clichy, France

Received for publication 3 October 1974.
}

means of distinguishing between hepatic parenchymal disease and biliary obstruction or intrahepatic cholestasis. In practice, such distinction has not been possible because storage capacity and $\mathrm{Tm}$ are generally both decreased in parenchymal disease and cholestasis (Wheeler et al, 1960c). The reason why storage capacity is substantially decreased during cholestasis (especially during biliary obstruction) has never been satisfactorily explained. It is known that competition may occur for hepatic uptake (and therefore, possibly, storage) between bile acids and BSP (Bourdon, Fauvert, Nicollo, and d'Auteuil, 1960; Wheeler et al, 1960c). Since serum bile acid concentration is increased during biliary obstruction, these studies were undertaken to test the hypothesis that the decrease in storage capacity observed during biliary obstruction could be related to competition between bile acids and bromsulphthalein. The results indicate that the infusion of bile acids significantly decreases both BSP storage capacity and BSP transfer rate from plasma to liver. 


\section{Material and Methods}

EXPERIMENTAL PROTOCOLS

Two types of experiments were performed.

1 Measurement of BSP,Tm, and storage capacity (S) Bromsulphthalein $\mathrm{Tm}$ and $\mathrm{S}$ were measured using the double-infusion technique of Wheeler et al (1960c) in six unanaesthetized mongrel dogs weighing 16 to $23 \mathrm{~kg}$. In each dog, two measurements were performed, the first with an intravenous infusion of 0.15 $\mathrm{M} \mathrm{NaCl}$ (control experiment), the second, at least three weeks later, with an intravenous infusion of sodium dehydrocholate in $\mathrm{H}_{2} \mathrm{O}$ (Theraplix Laboratories, Paris, France) at a rate of $95 \mu \mathrm{mol} . \mathrm{min}^{-1}$ (group A). In addition, in order to compare the influence of dehydrocholate on storage capacity and $\mathrm{Tm}$ to that of taurocholate, storage capacity and $\mathrm{Tm}$ were measured in three dogs (group B) with a sodium taurocholate infusion. Two of these dogs ( $G$ and $H)$ had already been investigated with dehydrocholate in group A. Sodium taurocholate (Sigma, St Louis, Missouri, USA), in glucose $50 \mathrm{~g} / 1: \mathrm{Na}_{2} \mathrm{CO}_{3} 0 \cdot 1 \mathrm{M}$, $1: 1, \mathrm{v} / \mathrm{v}$ was infused at a rate of $110 \mu \mathrm{mol} . \mathrm{min}^{-1}$. The volume of water infused was $0.2 \mathrm{ml} \cdot \mathrm{min}^{-1}$ in the three groups of experiments. In each case, the bile salt infusion was started $30 \mathrm{~min}$ before the BSP infusion. The rate of bile salt infusion was chosen to approximate the known maximal rate of taurocholate excretion into bile (Wheeler, Mancusi-Ungaro, and Whitlock, 1960b; O'Máille, Richards, and Short, 1965). Dehydrocholate was used because, in contrast to taurocholate, it does not produce haemolysis at high infusion rates. At the end of each experiment, plasma volume was measured using a standard dilution method with ${ }^{125}$ I-labelled human serum albumin (Centre National de Transfusion Sanguine, Paris, France).

\section{Compartmental analysis of BSP disappearance curve}

In the six dogs of group $\mathrm{A}$, after a single intravenous injection of $5 \mathrm{mg} . \mathrm{kg}^{\text {body weight }}{ }^{-1}$ of BSP, blood samples were taken at two, four, six, nine, 12, 16, $20,25,30,35,40,45,50,60,70,80$, and $90 \mathrm{~min}$ and plasma BSP concentration was measured. Again, in each dog, two experiments were performed, the first under a continuous intravenous infusion of $0.15 \mathrm{M}$ $\mathrm{NaCl}$ at a rate of $0.2 \mathrm{ml} . \mathrm{min}^{-1}$ (control experiment), the second under an intravenous infusion of sodium dehydrocholate, at a rate of $95 \mu \mathrm{mol} \cdot \mathrm{min}^{-1}$, in a volume of $0.2 \mathrm{ml} . \mathrm{min}^{-1}$. The infusions of $\mathrm{NaCl}$ or dehydrocholate were started $30 \mathrm{~min}$ before the injection of BSP.

\section{ANALYTICAL PROCEDURES AND \\ CALCULATIONS}

Bromsulphthalein concentration in plasma was measured after appropriate dilution in $\mathbf{K H}_{2} \mathbf{P O}_{4}$ $0 \cdot 15 \mathrm{M}: \mathrm{Na}_{2} \mathrm{HPO}_{4} \mathbf{0} \cdot 11 \mathrm{M}, 4: 7, \mathrm{v} / \mathrm{v}$ buffer, $\mathrm{pH} 6 \cdot 7$, after alkalization with $\mathrm{K} \mathrm{OH} 3.6 \mathrm{~N}$ in a Zeiss PM Q2 spectrophotometer at $580 \mathrm{~nm}$. The plasma disappearance curve of BSP was subjected to compartmental analysis (Barber-Riley, Goetzee, Richards, and Thomson, 1961) using a two-compartment model system and a conventional graphic technique. The graph of the concentration at time $\mathrm{t}(\mathrm{Ct})$ may be described in this model as the sum of two exponential functions; these two functions are respectively $\mathrm{Ae}^{-\mu \mathrm{t}}$ and $\mathrm{Be}^{-\nu \mathrm{t}}$. The plasma BSP concentration at time $\mathrm{t}$ is: $\mathrm{Ct}=\mathrm{Ae}^{-\mu \mathrm{t}}+\mathrm{Be}^{-\nu \mathrm{t}}$. The fractional transfer rates were calculated according to the following formulae (Barber-Riley et al, 1961):

Plasma to liver transfer rate: $\mathbf{k}_{21}=(\mathrm{A} \mu+\mathrm{B} \nu) /(\mathrm{A}$ + B)

Liver to bile transfer rate: $\mathbf{k}_{\mathbf{3 2}}=\mu \nu / \mathbf{k}_{\mathbf{2 1}}$

Liver to plasma transfer rate: $\mathbf{k}_{12}=(\mu+\nu)-\left(\mathbf{k}_{21}\right.$ $+\mathrm{k}_{32}$ )

The transfer rate from bile to liver is assumed to be negligible $\left(k_{23} \simeq 0\right)$. The comparison of means was performed with the Student's t test for paired data.

\section{Results}

The influence of dehydrocholate on BSP Tm and storage capacity in the dogs of group A is indicated

\begin{tabular}{|c|c|c|c|c|c|}
\hline \multirow[t]{2}{*}{ Dog } & \multicolumn{3}{|c|}{ Storage Capacity $\left(\mathrm{mg} \cdot \mathrm{mg}^{-1} .100 \mathrm{ml}^{-1}\right)$} & \multicolumn{2}{|c|}{ Biliary Transport Maximum (mg.min ${ }^{-1}$ ) } \\
\hline & Control & & Dehydrocholate & Control & Dehydrocholate \\
\hline $\begin{array}{l}\mathbf{A} \\
\mathbf{B} \\
\mathbf{C} \\
\mathbf{D} \\
\mathbf{E} \\
\mathbf{F}\end{array}$ & $\begin{array}{l}70 \cdot 0 \\
72 \cdot 0 \\
36 \cdot 0 \\
37 \cdot 0 \\
18 \cdot 0 \\
41 \cdot 0\end{array}$ & & $\begin{array}{r}29 \cdot 0 \\
23 \cdot 0 \\
10 \cdot 0 \\
12 \cdot 0 \\
7 \cdot 5 \\
27 \cdot 0\end{array}$ & $\begin{array}{l}4 \cdot 5 \\
6 \cdot 0 \\
3 \cdot 8 \\
6 \cdot 3 \\
4 \cdot 1 \\
4 \cdot 1\end{array}$ & $\begin{array}{l}3.8 \\
4.7 \\
2.8 \\
2.6 \\
1.6 \\
3.9\end{array}$ \\
\hline $\begin{array}{l}\text { Mean } \\
\text { SD } \\
\text { P }\end{array}$ & $\begin{array}{l}47 \cdot 0 \\
21 \cdot 0\end{array}$ & $<0.001$ & $\begin{array}{r}18 \cdot 0 \\
9 \cdot 0\end{array}$ & $\begin{array}{l}4 \cdot 8 \\
1 \cdot 1\end{array}$ & $\begin{array}{l}3.2 \\
1 \cdot 1\end{array}$ \\
\hline
\end{tabular}

Table I Influence of dehydrocholate on BSP relative storage capacity and biliary transport maximum in the dog 


\begin{tabular}{|c|c|c|c|c|}
\hline \multirow[t]{2}{*}{ Dog } & \multicolumn{2}{|c|}{ BSP Relative Storage Capacity $\left(\mathrm{mg} \cdot \mathrm{mg}^{-1} .100 \mathrm{ml}^{-1}\right)$} & \multicolumn{2}{|c|}{ Biliary Transport Maximum (mg.min ${ }^{-1}$ ) } \\
\hline & Dehydrocholate & Taurocholate & Dehydrocholate & Taurocholate \\
\hline $\begin{array}{l}G^{1} \\
Y^{1} \\
I\end{array}$ & $\begin{array}{r}12.0 \\
7.5 \\
31.0\end{array}$ & $\begin{array}{r}3.5 \\
0.0 \\
22.0\end{array}$ & $\begin{array}{l}2.6 \\
1.6 \\
2.7\end{array}$ & $\begin{array}{l}3 \cdot 3 \\
2 \cdot 2 \\
2 \cdot 9\end{array}$ \\
\hline Mean & $17 \cdot 0$ & $8 \cdot 5$ & $2 \cdot 3$ & $2 \cdot 8$ \\
\hline
\end{tabular}

Table II Comparison of the influence of dehydrocholate and taurocholate on BSP relative storage capacity and biliary transport maximum in three dogs ${ }^{1}$

${ }^{1}$ Dogs $\mathbf{G}$ and $\mathbf{H}$ are also dogs $\mathrm{D}$ and $\mathrm{E}$ of group $\mathbf{A}$

\begin{tabular}{|c|c|c|c|c|c|c|}
\hline \multirow[t]{2}{*}{ Dog } & \multicolumn{2}{|c|}{$k_{21}\left(m g . m g^{-1} \cdot \min ^{-1}\right)$} & \multicolumn{2}{|c|}{$k_{12}\left(m g \cdot m g^{-1} \cdot m^{-1}\right)$} & \multicolumn{2}{|c|}{$k_{32}\left(m g \cdot m g^{-1} \cdot m i n^{-1}\right)$} \\
\hline & Control & Dehydrocholate & Control & Dehydrocholate & Control & Dehydrocholate \\
\hline $\begin{array}{l}\text { Mean } \\
\text { SD } \\
\mathbf{P}\end{array}$ & $\begin{array}{l}0.280 \\
0.055\end{array}$ & $\begin{array}{l}0.120 \\
0.035\end{array}$ & $\begin{array}{l}0.016 \\
0.007\end{array}$ & $\begin{array}{l}0.030 \\
0.020\end{array}$ & $\begin{array}{l}0.033 \\
0.017\end{array}$ & $\begin{array}{l}0.013 \\
0.004\end{array}$ \\
\hline
\end{tabular}

Table III Influence of dehydrocholate on BSP transfer rates from plasm to liver $\left(k_{21}\right)$, from liver to plasma $\left(k_{12}\right)$, and from liver to bile $\left(k_{32}\right)$ in the dog

in table I. Values for storage capacity were significantly lower when a dehydrocholate infusion was administered than in the controls. The mean decrease was $61 \%$. The Tm was also significantly reduced when dehydrocholate was infused compared with controls: the mean decrease was $33 \%$. A comparison between the influence of dehydrocholate and taurocholate in the three dogs of group B appears in table II. Storage capacity was lower in taurocholateinfused than in dehydrocholate-infused animals. The influence of both bile salts on Tm was similar.

The influence of dehydrocholate on BSP transfer rates is indicated in table III. The plasma to liver transfer rate $\left(k_{21}\right)$ was significantly lower under dehydrocholate infusion than in the controls. The mean decrease was $57 \%$. The liver to bile transfer rate $\left(\mathbf{k}_{32}\right)$ was also significantly lower under dehydrocholate infusion than in controls. The mean decrease was $€ 1 \%$. The liver to plasma transfer rate $\left(\mathrm{k}_{12}\right)$ was not significantly different in the two groups.

\section{Discussion}

The results indicate that a dehydrocholate infusion causes a parallel decrease in BSP storage capacity, and BSP transfer rate from plasma to liver; in addition, the BSP Tm and transfer rate from liver to bile are both reduced.

The reductions in storage capacity and the transfer rate from plasma to liver could be due either to diminished transfer through the sinusoidal membrane or to a decrease in binding to the cytoplasmic proteins $Y$ and Z (Levi, Gatmaitan, and Arias, 1969) or both. The available evidence suggests that bile salts are not bound to the $\mathrm{Y}$ protein: for instance, taurocholate did not displace BSP from the $Y$ protein in vitro (Levi et al, 1969; Litwack, Ketterer, and Arias, 1971). Although most of the experiments in this work were performed with dehydrocholate, a semi-synthetic triketocholanoic bile salt, the results obtained with taurocholate were qualitatively similar. If the effect of bile salts on BSP storage capacity and transfer rate is not due to interference with $\mathrm{Y}$ binding, it might be due to interference with transport through the sinusoidal plasma membrane. It has already been reported that dehydrocholate decreases the plasma to liver transfer rate of rose bengal (Kelman-Sraer, Erlinger, Peignoux, and Benhamou, 1973), a phthalein dye structurally related to BSP, as well as BSP uptake (Andrews and Richards, 1960; Wheeler et al, 1960c). Bromsulphthalein 'carriers' in the liver cell membrane have been postulated (Frezza, Tiribelli, Panfili and Sandri, 1974). A taurocholate-binding protein has recently been identified in isolated liver cell membranes (Accatino and Simon, 1974) and taurocholate transport through the liver cell membrane has been postulated to be carrier mediated (Glasinović, Dumont, Duval, and Erlinger, 1973; Reichen and Paumgartner, 1973). The results of these experiments 
suggest that the transport of bile salts and BSP across the liver cell membrane may share a common step. Whatever the molecular mechanism involved, these findings suggest that the decrease in BSP disappearance rate and relative storage capacity (Wheeler et al, 1960c) observed during biliary obstruction could be due, as in our experiments, to an increased plasma bile salt concentration. Although bile salt concentration in blood has not been measured in our experiments, it is likely to be elevated when bile salts are infused at a rate approaching Tm (Wheeler et al, 1960b; O'Máille et al, 1965).

The second group of findings is the decrease of BSP Tm and transfer rate from liver to bile. This is apparently in contrast to the increase in $\mathrm{Tm}$ observed in several species, including the dog, during taurocholate (Ritt and Combes, 1967; Gibson and Forker, 1972; Barnhart, Ritt, Ware, and Combes, 1973; Erlinger and Dumont, 1973) or dehydrocholate infusions (Bourdon et al, 1960; Ritt et al, 1967). However, in all these experiments, bile salt infusion was started after BSP infusion. In our experiments, as well as in experiments in rats (Bourdon et al, 1960), dehydrocholate was administered before BSP; it is conceivable that under these conditions, because of the interference with uptake discussed above, the input of BSP into the liver is insufficient for the $\mathrm{Tm}$ to be increased, or even maintained. In addition, it should be pointed out that a reduction in $\mathrm{Tm}$ has also been observed during prolonged infusion of bile salts in the dog (Barnhart et al, 1973; Gibson and Forker, 1974). Finally, it is noteworthy that the rose bengal transfer rate from liver to bile was increased by dehydrocholate (Kelman-Sraer et al, 1973), whereas, in our experiments, the BSP transfer rate was decreased. The reason for this discrepancy is unknown; it could be due to the existence of two separate carriers for the transport into bile of BSP and rose bengal; another argument for this hypothesis is that phenobarbital, which increases BSP Tm in the rat, does not increase rose bengal Tm (Berthelot, Dhumeaux, and Préaux, 1969).

This work was supported in part by a grant No 73 71643 from DGRST.

\section{References}

Accatino, L., and Simon, F. R. (1974). Characterization and properties of a liver plasma membrane bile salt binding protein. Third Bile Acid Meeting: Advances in Bile Acid Research. Freiburg i.Br., June 13-15, 1974

Andrews, W. H. H., and Richards, T. G. (1960). The activity of bile salts and certain detergents on the hepatic storage and protein- binding of sulphobromophthalein. Quart. J. exp. Physiol., 45, 275-283.

Barber-Riley, G., Goetzee, A. E., Richards, T. G., and Thomson, J. Y. (1961). The transfer of bromosulphthalein from the plasma to the bile in man. Clin. Sci., 20, 149-159.

Barnhart, J., Ritt, D., Ware, A., and Combes, B. (1973). A comparison of the effects of taurocholate and theophylline on BSP excretion in dogs. In The Liver. Quantitative Aspects of Structure and Function, edited by G. Paumgartner and R. Preisig, pp. 315 325. Karger, Basle.

Berthelot, P., Dhumeaux, D., and Préaux, A. M. (1969). Comparaison de l'action du phénobarbital sur les métabolismes de la bilirubine et de diverses phtaléines chez le rat. (Abstr.). Biol. Gastro-entérol. (Paris), 2, 219-220.

Bourdon, G., Fauvert, R., Nicollo, F., and d'Auteuil, P. (1960) Recherches sur le mécanisme des perturbations apportées par le déhydrocholate de sodium à l'épuration sanguine et l'elimination biliaire de la bromesulphonephtaléine. Rev. int. Hêpat., 10, 1215-1246.

Erlinger, S., and Dumont, M. (1973). Influence of canalicular bile flow on sulfobromophthalein transport maximum in bile in the dog. In The Liver. Quantitative Aspects of Structure and Function, edited by G. Paumgartner, and R. Preisig, pp. 306-314. Karger, Basel.

Frezza, M., Tiribelli, C., Panfili, E., and Sandri, G. (1974). Evidence for the existence of a carrier for bromsulphophthalein in the liver cell plasma membrane. FEBS Letters, 38, 125-128.

Gibson, G. E., and Forker, E. L. (1972). Effect of taurocholate on net excretion of $\mathrm{S}_{35}$-BSP from liver cells to bile. (Abstr.). Fed. Proc., 31, 309.

Gibson, G. E., and Forker, E. L. (1974). Canalicular bile flow and bromosulfophthalein transport maximum: the effect of a bile salt-independent choleretic, SC-2644. Gastroenterology, 66, 1046-1053.

Glasinović, J. C., Dumont, M., Duval, M., and Erlinger, S. (1975). Hepatocell slar uptake of taurocholate in the dog. J. clin. Invest, (in press).

Javitt, N. B. (1970). Clinical and experimental aspects of sulfobromophthalein and related compounds. In Progress in Liver Diseases, edited by H. Popper and F. Schaffner, Vol. III, pp. 110-117. Grune and Stratton, New York.

Kelman-Sraer, J., Erlinger, S., Peignoux, M., and Benhamou, J. P (1973). Influence of dehydrocholate on hepatic uptake and biliary excretion of rose bengal in the rabbit. Biomed. Expr., $19,415-418$.

Leevy, C. M. (1961). Dye extraction by the liver. In Progress in Liver Diseases, edited by $\mathbf{H}$. Popper and F. Schaffner, Vol. I, pp. 174-186. Grune and Stratton, New York.

Levi, A. J., Gatmaitan, Z., and Arias, I. M. (1969). Two hepatic cytoplasmic protein fractions, $Y$ and $Z$, and their possible role in the hepatic uptake of bilirubin, sulfobromophth: lsin, and other anions. J. clin. Invest., 48, 2156-2167.

Litwack, G., Ketterer, B., and Arias, I. M. (1971). Ligandin: a hepatic protein which binds steroids, bilirubin, carcinogens and a number of exogenous organic anions. Nature (Lond.), 234, 466-467.

O'Máille, E. R. L., Richards, T. G., and Short, A. H. (1965). Acute taurine depletion and maximal rates of hepatic conjugation and secretion of cholic acid in the dog. J. Physiol. (Lond.), 180, 67-79.

Reichen, J., and Paumgartner, G. (1973). Michaelis-Menten kinetics and diffusion describing hepatic taurocholate uptake. (Abstr.) Digestion, 8, 545.

Ritt, D. J., and Combes, B. (1967). Enhancement of apparent excretory maximum of sulfobromophthalein sodium (BSP) by taurocholate and dehydrocholate. (Abstr.) J. clin. Invest., 46, 1108.

Wheeler, H. O., Epstein, R. M., Robinson, R. R., and Snell, E. S. (1960a). Hepatic storage and excretion of sulfobromophthalein sodium in the dog. J. clin. Invest., 39, 236-247.

Wheeler, H. O., Mancusi-Ungaro, P. L., and Whitlock, R. T. (1960b). Bile salt transport in the dog. (Abstr.) J. clin. Invest., 39, 10391040.

Wheeler, H. O., Meltzer, J. I., and Bradley, S. E. (1960c). Biliary transport and hepatic storage of sulfobromophthalein sodium in the unanesthetized dog, in normal man and in patients with hepatic disease. J. clin. Invest., 39, 1131-1144. 